\title{
Performance of an immunochromatography test for vivax malaria in the Amazon region, Brazil
}

\section{Desempenho de um teste de imunocromatografia para malária por $P$. vivax na Amazônia}

\author{
Alberto Ferreira Figueiredo Filho ${ }^{\mathrm{a}, *}$, Maria Cristina Figueredo ${ }^{\mathrm{a}}$, José Maria Nascimento ${ }^{\mathrm{a}}$, \\ Vanja Suely Pachiano Calvosa a , Marinete Marins Póvoa ${ }^{a}$ and Ricardo Luiz Dantas Machado ${ }^{a, b}$
}

aServiço de Parasitologia do Instituto Evandro Chagas. Belém, PA, Brazil. bepartamento de Doenças Dermatológicas, Infecciosas e Parasitárias da Faculdade de Medicina de São José do Rio Preto. São Jose do Rio Preto, SP, Brazil

\section{Keywords}

Malaria, vivax, diagnosis. Plasmodium vivax. Cromatography.

\section{Descritores}

Malária vivax, diagnóstico.

Plasmodium vivax. Cromatografia.

\begin{abstract}
The study was carried out to evaluate the diagnostic performance of the ICT malaria $\mathrm{Pf} / \mathrm{Pv}^{\mathrm{TM}}$ test for vivax malaria diagnosis in Belém, Amazon region, Brazil. The results of blood malaria parasites examination using an immunochromatography test were compared with thick blood film (TBF) examination. It was also evaluated the performance of this test storaged at three different temperatures $\left(25^{\circ} \mathrm{C}, 30^{\circ} \mathrm{C}\right.$, and $37^{\circ} \mathrm{C}$ ) for 24 hours before use. Overall sensitivity of ICT $\mathrm{Pf} / \mathrm{Pv}^{\mathrm{TM}}$ was $61.8 \%$ with a specificity of $100 \%$, positive and negative predictive value of $100 \%$ and $71.8 \%$, respectively and accuracy of $80.6 \%$. The test sensitivity was independent of the parasite density. This test needs to be further reviewed in order to have better performance for $P$. vivax malaria diagnosis.
\end{abstract}

\begin{abstract}
Resumo
Avaliação do teste ICT malaria Pf/P $v^{T M}$ para o diagnóstico da malária por $\mathrm{P}$. vivax em Belém, Estado do Pará. Foram comparados os resultados do teste imunocromatográfico com a gota espessa $(G E)$ e avaliados o comportamento desse teste, estocado a três temperaturas distintas $\left(25^{\circ} \mathrm{C} / 30^{\circ} \mathrm{C} / 37^{\circ} \mathrm{C}\right), 24$ horas antes de seu uso. A sensibilidade do ICT malaria Pf/Pv ${ }^{T M}$ foi de 61,8\% com especificidade de $100 \%$, valores preditivo positivo e negativo de $100 \%$ e $71,8 \%$, respectivamente, $e$ acurácia de 80,67\%. A sensibilidade desse teste foi independente da densidade parasitária. Este teste necessita de reavaliação para melhorar o seu comportamento no diagnóstico da malária por $\mathrm{P}$. vivax.
\end{abstract}

Malaria is one of the most prevalent infectious diseases in tropical areas world-wide and is one of the main causes of human morbidity in the Amazon region, north of Brazil. In this area, Plasmodium vivax is the most common human malaria parasite, causing more than $80.2 \%$ of all cases reported in 2000 .

The rapid and accurate diagnosis of malaria is essential for reducing its morbidity and mortality as well as for its control. The diagnosis of malaria has been tradi- tionally based on microscopic examination of thick and thin blood films. Although simple and cheap, this procedure is however labor-intensive, time consuming and dependent upon training and expert knowledge of morphologic differentiation of plasmodial species. $^{3}$ Alternative immunochromatography tests have been developed, particularly for Plasmodium falciparum that showed to be effective, quick and easy to use. ${ }^{1} P$. vivax malaria blood samples from Turkey were analyzed by ICT-Malaria $\mathrm{Pv}^{\mathrm{TM}}$ test (it detects $P$.
*Aluno bolsista da Faculdade de Medicina da Universidade Federal do Pará

Received on 9/9/2002. Reviewed on 15/2/2003. Approved on 12/3/2003. 
vivax histidine-rich protein (HRP)-2 antigen) and showed $85.7 \%$ sensitivity, $100 \%$ specificity, and positive and negative predictive values of $100 \%$ and $87.1 \%$, respectively. ${ }^{2}$ It has been suggested that this test is simple, rapid and reliable, allowing diagnosis where traditionally diagnostic tests are not available (rural and remote areas). Recently, it came out the ICT Malaria $\mathrm{Pf} / \mathrm{Pv}^{\mathrm{TM}}$ (ICT-Malaria Pf/Pv, AMRAD, Australia), a commercial in-vitro immunochromatography test for the detection and speciation of both P. falciparum and $P$. vivax malaria parasites. The aim of this study is to evaluate the diagnostic performance of the ICT Pf/ $\mathrm{Pv}^{\mathrm{TM}}$ test for diagnosis of vivax malaria in Belém, Amazon region, Brazil.

Subjects seen at the Evandro Chagas Institute, Belém, from January to March 2000 with symptoms and signs suggestive of malaria and later had a positive slide test for $P$. vivax malaria were randomly tested using ICT $\mathrm{Pf} / \mathrm{Pv}^{\mathrm{TM}}$. Informed consent was obtained and symptoms details were registered. There were 20 asymptomatic individuals in the negative control groups, and the same number of $P$. falciparum infected individuals with positive thick blood film (TBF) was selected. $P$. vivax malaria patients had been treated with chloroquine $25 \mathrm{mg} / \mathrm{kg}$ of body weight divided in three days $(10 \mathrm{mg} / \mathrm{kg}$ in day 1 and $7.5 \mathrm{mg} / \mathrm{kg}$ in days 2 and 3) plus primaquine $0.25 \mathrm{mg} / \mathrm{kg}$ of body weight for 14 days starting five days after the vivax malaria diagnosis.

The results of blood obtained through finger-prick and immediate evaluation using ICT Malaria $\mathrm{Pf} / \mathrm{Pv}^{\mathrm{TM}}$ test (as by the manufacturer's instructions) on day 0 and days 1,2, 3 and 4 after treatment start were compared with standard microscopy examination of malaria parasites in TBF. Fifteen samples were also evaluated using ICT Malaria $\mathrm{Pf} / \mathrm{Pv}^{\mathrm{TM}}$ test storaged at three different temperatures $\left(25^{\circ} \mathrm{C}, 30^{\circ} \mathrm{C}\right.$ and $\left.37^{\circ} \mathrm{C}\right)$ for 24 hours before use. TBF were examined by independent experienced microscopists who were unaware of the results, following the World Health Organization ${ }^{5}$ recommended procedures.

In order to compare the performance of ICT $\mathrm{Pf} / \mathrm{Pv}^{\mathrm{TM}}$ test, 30 vivax malaria patients before (day 0 ) and after chloroquine treatment (day 1 to 4 ) were included in the study. On day 0,30 samples of $P$. vivax patients showed parasite density between 200 and 7,750 infected red blood cells $/ \mathrm{mm}^{3}$, while on day 1 the parasitemia had ranged from 10 to 1,020 infected red blood cells $/ \mathrm{mm}^{3}$. Three samples were negative. On day 215 samples had parasite density between 10 and 300 infected red blood cells $/ \mathrm{mm}^{3}$, and $15 \mathrm{sam}$ ples were negative. The parasitemia in day 3 was detected only in four samples and ranged from 10 to 40
Table - Performance of the ICT Malaria Pf/Pv ${ }^{T M}$ test in diagnosing Plasmodium vivax in Belém, Brazil, compared to thick blood film (TBF).

\begin{tabular}{|c|c|c|c|}
\hline \multirow[b]{2}{*}{ ICT Pf/Pv ${ }^{T M}$ test } & \multicolumn{3}{|c|}{ Microscopy (TBF) } \\
\hline & Positive & Negative & Total \\
\hline Positive & 47 & 0 & 47 \\
\hline Negative & 29 & 74 & 103 \\
\hline Total & 76 & 74 & 150 \\
\hline
\end{tabular}

Sensitivity: $61,84 \%$; specificity: $100 \%$, positive predictive value: $100 \%$; negative predictive value: $71,84 \%$ and accuracy: $80,66 \%$

infected red blood cells $/ \mathrm{mm}^{3}$. In day 4 all 30 samples were negative. The ICT Pf/Pv ${ }^{\mathrm{TM}}$ test detected $P$. vivax in 28 samples in day 0 , while in day 1 it was detected in sixteen and in day 2 only in four samples. None $P$. vivax sample was detected using ICT $\mathrm{Pf} / \mathrm{Pv}^{\mathrm{TM}}$ test in day 3. Both TBF and ICT Pf/Pv ${ }^{\mathrm{TM}}$ test were negative in day 4. The ICT Pf $/ \mathrm{Pv}^{\mathrm{TM}}$ was negative in all $20 \mathrm{sam}$ ples (control group) with no parasites in the microscopy examination. The ICT $\mathrm{Pf} / \mathrm{Pv}^{\mathrm{TM}}$ test detected all 20 P. falciparum samples that were seen in the microscopy examination.

A total of 150 paired samples were analyzed. The test performance was assessed in terms of its sensitivity and specificity. Overall sensitivity of ICT Pf $/ \mathrm{Pv}^{\mathrm{TM}}$ for vivax malaria diagnosis was $61.8 \%$, specificity of $100 \%$, positive and negative predictive values of $100 \%$ and $71.8 \%$, respectively and accuracy of $80.7 \%$ (Table). The results of ICT Pf $/ \mathrm{Pv}^{\mathrm{TM}}$ were variable for the three different temperatures tested. It was observed that the color of positive results (pink line) losses its intensity with increasing temperatures.

The great area of land and water, and the uncontrolled occupation of the Brazilian Amazon region, associated with the lack of personnel to carry out rapid diagnosis, all contribute to the elevated number of malaria cases in this region.

The Quantitative Buffy Coat ${ }^{\circledR}$ and serological tests are useful but have limitations for the diagnosis of malaria infections and alternative methods are needed to overcome these problems. Molecular techniques are sensitive, accurate and specific ${ }^{4}$ but expensive and require expert knowledge. Complementary and alternative diagnosis methods not dependent on microscopy are commercially available.

Although the ICT $\mathrm{Pf} / \mathrm{Pv}^{\mathrm{TM}}$ test is known for its ease of use even for personnel not familiar with the test format, it has showed variable results in P. vivax detection and low sensitivity in the present study. The study results suggest that differences in the sensitivity of ICT $\mathrm{Pf} / \mathrm{Pv}^{\mathrm{TM}}$ test for vivax malaria infections were independent of $P$. vivax density in blood sam- 
ples. Storage temperature is a crucial factor for the efficiency of the ICT Pf/Pv $\mathrm{Pv}^{\mathrm{TM}}$ test, especially in the north of Brazil where temperatures can reach more than $30^{\circ} \mathrm{C}$ (maximum storage temperature recommended by the kit).

Although the cost of ICT Pf/Pv ${ }^{\mathrm{TM}}$ (US\$ 1.50) is higher than microscopy technique (US\$ 0.70), this method is simple and rapid, allowing diagnosis where specialized laboratory and personnel are not available. This test can play a useful role in assessing $P$. vivax malaria diagnosis in developing countries, but

\section{REFERENCES}

1. Abul Faiz MA, Rashid R, Palit R, Rahman MR, Bin Yunus $E$, Hussain $A$ et al. ParaSight ${ }^{T M}$ - F test results in cerebral malaria patients before and after treatment in Chittagong Medical College Hospital, Bangladesh. Trans R Soc Trop Med Hyg 2000;94:56-7.

2. Araz E, Tanyhksel M, Ardic N, Tabuk C. Performance of a commercial immunochromatografic test for the diagnosis of vivax malaria in Turkey. Trans $R$ Soc Trop Med Hyg 2000;94:55-6. it needs to be further reviewed for a better performance. The TBF is still the best indicator of $P$. vivax malaria in infected patients.

The study protocol was reviewed and approved by the Research Board of the Evandro Chagas Institute.

\section{ACKNOWLEDMENTS}

To all patients enrolled in this study and staff of the Malaria Laboratory at the Evandro Chagas Institute for their technical assistance.

3. Chiodini PL. Non-microscopic methods for diagnosis of malaria. Lancet 1998;351:80-1.

4. Machado RLD, Garret DO, Adagu IS, Warhurst DC, Póvoa MM. Simplified diagnosis of malaria infection: GFM/PCR/ELISA a simplified nucleic acid amplification technique by PCR/ELISA. Rev Inst Med Trop S Paulo 1998;40:333-4.

5. World Health Organization. Basic malaria microscop. Geneva; 1991. Part I p.17-68. 